\title{
Measuring Corporate Social Responsibility in Sport Industry: Development and Validation of Measurement Scale
}

\author{
${ }^{1}$ Amir Montazeri, ${ }^{1}$ Mahdi Talebpour ${ }^{*},{ }^{2}$ Reza Andam, ${ }^{3}$ Anoshirvan Kazemnejad \\ ${ }^{1}$ Faculty of Sport Sciences, Ferdowsi University of Mashhad, Mashhad, Iran. ${ }^{2}$ Faculty of Physical Education and \\ Sport Sciences, Shahrood University of Technology, Shahrood, Iran. ${ }^{3}$ Faculty of Medical Sciences, Tarbiat Modares \\ University, Tehran, Iran.
}

\begin{abstract}
Background. While more and more sport organizations broadly acknowledge their ability at delivering social values, corporate social responsibility (CSR) is rapidly growing at a significant rate across the professional sport industry and its related organizations. Despite the growing body of research in this area, measuring CSR is still problematic. Objectives. Therefore, the aim of this study is to provide an efficient, valid, and reliable measure of CSR reflecting the responsibilities of sport industry. Methods. Based on a proposed conceptual framework of CSR, a scale was developed via a standard procedure for developing instrument measures. In this study, to determine and assess the underlying factorial structure, convergent and discriminate validity of measurement scale, exploratory and confirmatory factor analysis was performed. Data was collected from 640 sport fans in Iran's Football Premier League. Results. The results of the analysis provided a five-dimensional structure of CSR in sport, such as economic, philanthropic, ethical, legal, and environmental issues. These dimensions explained $50.827 \%$ of the total variance. In addition, the KMO measure was computed and the results indicated an index of 0.927. Moreover, the values of Cronbach's alpha obtained for five factors ranged from 0.848 to 0.967 . The results show the reliability and validity of this new scale in sport industry. Conclusion. This study implies that from a consumer's perspective, CSR is perceived as a set of attributes; therefore, it is important for a professional sports team's management to understand fans' interest in social issues and fans' responses to various CSR programs.
\end{abstract}

KEY WORDS: Social Responsibility, Sustainable Development, Fans, Stakeholders, Premier League.

\section{INTRODUCTION}

Over the past seventy years, corporations have struggled with the issue of the company's responsibility to society. The idea that companies have social responsibilities has raised widespread interest and concern both in business and academia and also in the field of business administration (1). Today's business organizations are expected to display not only ethical behavior but also moral management. Social responsibility for many organizations and for the managers who work within them have become increasingly important (2). Today managers must also consider and evaluate the legal, ethical, moral, and social impact and responses of each of their decisions (3). Sport has the power to unite people with each other

*. Corresponding Author:

Mahdi Talebpour

E-mail:mtalebpour@um.ac.ir 
beyond cultural, social, ethnic and religious barriers (4), hence, sport industry has become one of the new and effective players in national and international markets (5). CSR is now a significant domain of focus for sport organizations including sport federations, sport leagues, and/or sport clubs, but has rarely been considered and measured in the sport management research field (6). So, sport organizations and sport managers need to be aware of developments about CSR and its strategic importance in sport just as corporate managers in other industries. CSR initiatives in sport can address social subjects more effectively because sport organizations have mass media distribution and power of communication and attractiveness for youth (2). In addition, CSR in sport can play a very important role in influencing stakeholder attitudes and buying behavior. Therefore, sport related bodies can benefit via their CSR approach like protecting and maintaining their reputation, developed loyalty of fans, competitive advantage, improved financial performance, recognition, improved relations with society, enhanced image, and performing ethical and altruistic behavior (6-8). The interest and growth in CSR measurement and reporting on the part of corporations has been influenced by several perceived and actual benefits attached to this activity. These benefits include things such as reduced operating costs, increased customer and employee loyalty and satisfaction, reduced regulatory risk, improved business practice and enhanced public image $(9,10)$. However, CSR has not been extensively examined within the context of sport (11), and one of the problems is the lack of information for CSR measurements in sports research. So, this study contributes to the literature by providing a new, valid, and reliable CSR measurement tool. Based on the proposed conceptual framework, this measurement tool reflects the CSR-related dimensions of sport industry as perceived by the customers (sport fans). This article is divided into three main sections. The first section presents the conceptual framework that forms the structural basis for the study. The second section presents the methodology, emphasizing the design of the measurement scale. Finally, a brief discussion of the results and future lines of research arising from this study are included.

Conceptual Bases: The Definition of CSR and the Role of Context

As the relationship between society and business has changed over the years, the definition and concept of CSR has been evolved as well. From the 1950s through the 1970s, the concept of CSR included corporate policies and management ethics; nevertheless, Jones (1980), started to include the other stakeholder groups, like customers, employees, suppliers, and neighboring communities, into the CSR concept and companies' responsibilities toward these groups (12). In the continuing evolution of the concept of corporate social responsibility, Mohr, Webb, and Harris (2001, p. 47), stated that "CSR is a company's commitment to minimizing or eliminating any harmful effects and maximizing its long-run beneficial impact on society" (13), in addition, Kotler and Armstrong (2015, p. 136), stated that "CSR is a commitment to enhance community well-being via discretionary business practices and contributions of corporate resources" (14). Recent academic analysis proposed that corporate social responsibility should properly be conceived of as "a set of descriptive categorizations of business activity, focusing on the impacts and outcomes for society, stakeholders and the firm ${ }^{\text {ee }}(15)$. Walker, Heere, Parent, and Drane (2010), argued that CSR has a meaning, but its concept is not the same for everyone (16), thus, the meaning of CSR is different based on the business under study and the attitude of the stakeholders involved (17-19). Consequently, the literature regarding this concept has occasionally been described as lacking cohesion, consensus, and theoretical maturity, thus resulting in great confusion and ambiguity (20). Recently, many new definitions have emerged, highlighting the contextual nature of CSR in the absence of a universal definition of this concept (19). In this sense, many definitions of CSR are based on two fundamental ideas. The first is that business has responsibilities beyond their economic activities and mere legal liability $(21,22)$. The second is that these responsibilities are not only attributed to shareholders but also impressive to wide range of stakeholders $(23,24)$. These two features are outlined in the European 
Commission's (2002) definition of CSR as the voluntary integration by organizations of social and environmental concerns in their business processes and their relationships with their stakeholders (25). This concept of CSR stresses that organizations should pay special attention to economic, social, and environmental aspects in their strategic planning (26-28).

Regarding this concept, three broad themes dominate the wider sport CSR literature: (1) conceptual work, (2) motives-oriented work, and (3) outcomes-oriented work. First, a small number of studies have focused on conceptual issues, with academic consideration being given to both the unique context in which sport operates and its significance to the CSR state of affairs. This conceptual stream has provided the theoretical foundation and practical orientation of CSR for sport researchers and managers, highlighting a number of determinants of CSR in professional sport (29). Secondly, the motiveoriented line of thought includes a number of studies that focus on the drivers and motives behind engagement to sport CSR, with multiple perspectives being apparent. The third and last stream of sport CSR research treats CSR as 'cause-related' marketing and stresses the importance of identifying the different impacts CSR programs may produce. This type of research involves studies that focus on related communication strategies and marketing programs from both the organization and consumer perspective. However, CSR is a term commonly employed by researchers in sport, the key question here is how should CSR be measured and what criteria should be used? The fact that CSR relates to many different organizational activities means that measuring CSR is complex. Carroll (1998), argues, the real question is whether valid and reliable measures can be developed (30). So, efforts to develop measurement scales must be intensified. In order to obtain a deeper understanding of this issue, it is necessary to consider the role of context in the practical articulation of CSR. As Sethi (1975), asserts, an evaluation of the social performance of organizations that ignores its cultural and sociopolitical environment is full of conceptual and methodological risks (31). Adaptive behavior of organizations with societal expectations is a basic assumption of CSR
$(31,32)$. Given that these expectations vary and depending on the context in which a firm operates, they may create problems and costs for the firm (17). Contextual aspects refer to the particular geographic, social, cultural, and economic policies of the locality in which organization carry out their operations (33). These features play an important role in determining the responsibilities of businesses and, consequently, in their responses to issues of CSR $(25,32)$. As argued by Stewart and Smith (1999), sport is different from other businesses in several ways which can assist in understanding why the management of sport organizations require the use of specific management techniques such as CSR (34). One of these is the irrational passion people develop for a sporting team, which may lead them to celebrate achievement, relate to performance outcomes, and personify to success or loss in a way that does not occur in other areas of economic or social activity. So, this article suggests a new scale for measuring CSR in the sport industry according to the theory of sustainable development, as this is one of the theoretical perspectives with the greatest relevance to the field of sport (35-41).

Academic Proposals for Measuring Corporate Social Responsibility

A variety of measurement methodologies can be found in academic literatures. Nevertheless, as discussed by D'Aprile and Talò (2013), there are various methods and techniques for measuring CSR activities (42). In fact, CSR has strong contextual characteristics, such that the concept and its component dimensions are determined by the particular characteristics of the companies in each industry and the context in which they operate $(17-19,21)$. A recent academic analysis identified five major methods which have been used (43), namely: (a) reputation indices and databases; (b) single and multiple issue indicators; (c) content analysis of corporate publications; (d) scales measuring CSR at the individual level; and (e) scales measuring CSR at the organizational level. The aim of this study is not to describe each of these approaches in detail but to focus on those aspects that are relevant to the present study, in terms of their main limitations. 
Reputation indices and databases, including the Fortune; the Kinder, Lydenberg and Domini (KLD) database in the US and the Canadian Social Investment Database (CSID), rate companies on several attributes, presumed to be related to CSR. Nevertheless, there are numerous problems with the use of such databases to measure CSR, including the restrictiveness of the attributes on which companies are rated and the ways in which companies are screened out of the databases (44). More fundamentally, regarding this research, no such database exists in the sport industry; so, this method is unavailable in sport industry. Many previous studies have sought to measure CSR via examination of single indicators such as environmental pollution control (45) or multiple indicators $(46,47)$. Nevertheless, this kind of measurement decision is often made because such data is easily available, rather than because the issues examined genuinely reflect a clear theoretical understanding of CSR. Moreover, as indicated by Maignan, Ferrell, and Ferrell (2005), the measures employed may not be indicative of the same underlying construct (48). In other studies, researchers have attempted to systematically analyze corporate publications to measure and compare companies CSR. Nevertheless, there are obvious problems associated with such an approach, as it does rely on how different companies report their activities. In addition, as reported by McGuire, Sundgren, and Schneeweis (1988), the data and information in report published by corporate organization may be different from the activities that were actually performed (49). The best it can probably achieve is a comparative analysis of how companies communicate their responsible behavior. The other main method of measuring CSR is questionnaire surveys, containing a number of questions (or items). These have previously been administered to individuals within organizations, attempting to measure CSR at either the individual or organizational level. Whereas the above methods attempt to measure the actual performance of CSR, this method measures the perceptions that stakeholders have of the concept. In this research, we focus on measuring Fans (as customers) perception as an interest group. This method seems the most appropriate because the other approaches include aspects that may not be evaluated by the consumer because it is difficult for consumers to obtain and store information about CSR (13), mainly due to the multidimensional nature of the concept (50).

Owing to the multidimensional construct of CSR, Carroll's model and articulation became one of the most frequently-cited CSR models. Carroll (1979), investigated CSR in a more exhaustive manner and synthesized previously conducted research with the definitions earlier offered into what he observed as the four 'facets' of CSR; economic, legal, ethical, and discretionary responsibilities (21). Based on these, the economic responsibility is the foundation on which all the other responsibilities rest, and refers to a company's wealthy and profitable operations. This implies that business organizations are basic economic units in society and should seek profitability by providing employment and good quality products at fair prices to customers and communities. The second responsibility in order is the legal obligation of businesses to obey the law. Legal responsibilities involve a company's operation according to legislations and under the governmental regulations. The third facet comprises the ethical responsibilities or duties that corporations have to address in order to operate in a socially acceptable manner. These ethical duties involve moral behaviors of doing what is right, just and fair; according to people's un-codified moral values and societal norms, and with the goal of preventing harm caused by others (51). Finally, discretionary responsibility refers to volunteer efforts characterized by the 'giving back' principle, often aimed at achieving philanthropic and altruistic objectives.

Subsequently, the definition of CSR was developed. In this regard, Freeman (1984) developed a stakeholder theory to explain managers' support for CSR and argues that managers must satisfy a multitude of different needs as occurring by different set of stakeholders. This means that corporations should not be exclusively focused on shareholders, or the firm owners, but they should satisfy the needs of different groups (consumers, employees, society in general, the environment, and the market) in the environment of the organization who can influence firm outcomes 
(52). Thereafter, perspective on the measurement of CSR suggests a focus on sustainable development. The special relevance of the environmental dimension makes this approach the most suitable for the present study because sport has emerged as a new substructure for the implementation of sustainable development (53). Moreover, this approach has helped to enhanced the understanding and clarity of CSR (54); in addition to being employed both for the management of this concept and at the operational level (55). From this perspective, the concept of CSR is reinforced as a multidimensional construct that equally emphasizes economic, social, and environmental aspects. Several authors support this approach, particularly in relation to sport industry (56-58).

In summary, a review of the literature reveals the existence of different methods and techniques for measuring socially responsible actions. Although all of these techniques have helped in the literature on CSR, they all have limitations. Thus, there is a need to establish a new measurement methodology for CSR that addresses the conceptual framework proposed. In this regard, the authors conceptualize CSR based on sustainable development, and stakeholder theory, and, as well as, considering the Carroll's (1979) model, to designate a multidimensional scale for the measurement of social responsibility in sport industry.

\section{MATERIALS AND METHODS}

Sampling and Data Collection. The analysis and evaluation of the socially responsible actions in sport was performed through a quantitative study. In particular, personal surveys of sport fans over 18 years of age were conducted in Iran's Football Premier League according to a structured questionnaire developed by the researchers. The sole restriction of the age criterion to spectators over the age of 18 was to eliminate the inclusion of children who did not have the decision-making power to attend the sports game on their own accord. Interviews were carried out to ensure their comfort and make sure that they took time to answer the questions calmly and thoughtfully. The participants were assured that all information gathered would be held confidential, presented in group from and only used in this study. The surveys distributed included a cover letter that explaining the project and requesting the participation, and the instrument. To design the research sample, a non-probability sampling procedure was chosen. Specifically, a convenience sample was used, as the researchers did not have access to a census of sport fans over the age of 18 in the Iran's Football Premier League and it was not possible to determine the probability of any particular element of the population being chosen for the sample. The questionnaire was collected to each of spectators who will attend sports games during available data collection period (January $29^{\text {th }}$ to February $2^{\text {nd }}$ ) during the 2015/2016 season of Iran's Premier League. One hour before games started, the researchers arrived at the stadium and began to hand out questionnaire to the early attending fans that were waiting in a line to purchases tickets. The on-site data collection strategy was conducted to ensure the respondent rate. The participants were able to ask questions regarding the questionnaire to avoid any possible misunderstanding. A total of 700 respondents participated in the survey; among them, 60 were deleted after a missing data check and outlier check. Total of 640 responses were used to analyze the data. Respondents were asked to evaluate their perception regarding the CSR performance of Football teams in Premier League. Table 1 displays the main characteristics of the research. The sociodemographic characteristic of respondents is included in Table 2.

Table 1. Quantitative Research Technical Record

\begin{tabular}{ll}
\hline Universe & Sport fans over 18 years of age \\
Scope & Iran (Iran's Football Premier League) \\
Data of fieldwork & January 2016 \\
Sample & 820 valid questionnaires \\
Processing of data & SPSS v. 22.0, LISREL v. 8.8 \\
\hline
\end{tabular}


Table 2. Sample characteristic

\begin{tabular}{|c|c|c|c|c|c|}
\hline & $\mathrm{N}$ & $\%$ & & $\mathrm{~N}$ & $\%$ \\
\hline Age: & & & Occupation: & & \\
\hline From 18 to 25 years & 232 & 36.3 & Student & 256 & 40.0 \\
\hline From 26 to 35 years & 216 & 33.8 & Employee & 126 & 19.7 \\
\hline From 36 to 45 years & 145 & 22.7 & Worker & 102 & 15.9 \\
\hline Over 46 years & 47 & 7.3 & etc. & 156 & 24.4 \\
\hline \multicolumn{6}{|l|}{ Education: } \\
\hline Diploma & 167 & 26.1 & Attendance in the stadium: & & \\
\hline Associate degree & 148 & 23.1 & 1 to 3 times during the season & 242 & 37.8 \\
\hline B.S. & 196 & 30.6 & 4 to 6 times during the season & 165 & 25.8 \\
\hline \multirow[t]{2}{*}{ MSc and Ph.D } & 129 & 20.2 & 7 to 10 times during the season & 87 & 13.6 \\
\hline & & & More than 10 times during the season & 146 & 22.8 \\
\hline
\end{tabular}

Design of the Measurement Scale. The authors followed Churchill's (1979), methodological proposal (59), based on a standard procedure for developing instrument measures, in order to design a new multi-item scale that includes items previously used in marketing literature regarding CSR. Previous researchers have used this procedure before $(43,60,61)$. The seven steps of measurement development recommended by Churchill (1979) are listed in the first two columns of Table 3. While Steps 1 to 4 address concerns of content validity, dimensionality, and internal consistency; Steps 5 to 7 address the concerns for reliability, criterion validity, and construct validity. Churchill (1979) suggested that can use these procedures with certain flexibilities and the recommended techniques can be replaced with other alternatives (59). The alternatives used in the current study included: (a) incorporating a panel of experts to generate samples of items; and (b) assessing reliability and validity of measurement scales with composite reliability, convergent validity, and discriminant validity $(43,62,63)$.

Table 3. Procedure for Developing Instrument Measures

\begin{tabular}{lll}
\hline $\begin{array}{l}\text { Procedures for developing better measures } \\
\text { suggested by Churchill (1979) }\end{array}$ & $\begin{array}{l}\text { Techniques recommended by } \\
\text { Churchill (1979) }\end{array}$ & $\begin{array}{l}\text { Techniques used in this } \\
\text { study }\end{array}$ \\
\hline $\begin{array}{ll}\text { 1. Specify domain of construct } \\
\text { 2. Generate sample of items }\end{array}$ & $\begin{array}{l}\text { Literature search } \\
\text { Literature search } \\
\text { Experience survey } \\
\text { Insight-stimulating examples } \\
\text { Critical incidents }\end{array}$ & $\begin{array}{l}\text { Literature search } \\
\text { Panel of experts }\end{array}$ \\
& Focus groups & Pilot study \\
3. Collect data & Coefficient alpha \\
4. Purify measure & Factor analysis & Factor analysis \\
& & Personal survey \\
5. Collect data & Composite reliability \\
6. Assess reliability & Split-half reliability & Convergent validity \\
7. Assess validity & Multitrait-multimethod matrix & Discriminant validity \\
\hline
\end{tabular}

Development of the Measurement Scale. First, the multidimensionality of the scale was conceptualized based on a literature review. In a second phase, items were generated through a literature review. In order to create an initial item pool, a list of statement was derived from 
the previous research in the literature $(21,43,60,61,64-69)$. This process led to an enlarged item pool including 74 items. In order to eliminate the unrelated items from the pool and the perceptual distortions of the researchers, these were reviewed through a panel of experts which was comprised of fifteen academics and experts in the sport area. Finally, a scale including 40 items was constructed. In the next step, to test and purify the measure, a quantitative study based on pilot test was conducted. It is essential to identify flaws and handicaps that might be encountered in the fullscale study. This step was only seen as a preliminary analysis of the scale and to explore the CSR factors in sport industry.

Respondents were asked to rate their perceptions of what their teams actually do about CSR rather than what the teams should do. Initially, the measurement scale included 40 items. All of the items were measured using a 7point Likert scale, in which a score of 1 indicates strongly disagree with the statement, and a score of 7 signifies total agreement with the statement. After collecting the data in phase 3, we first conducted an Exploratory Factor Analysis in phase 4. "EFA is a data-driven approach such that no specifications are made in regard to the number of latent factors (initially) or to the pattern of relationships between the common factors and the indicators (i.e., the factor loadings). Rather, the researcher employs EFA as an exploratory or descriptive technique to determine the appropriate number of common factors and to uncover which measured variables are reasonable indicators of the various latent dimensions (e.g., by the size and differential magnitude of factor loadings)" (70). Hence, scale items were analyzed using the principal components method of factor analysis with VARIMAX rotation (Table 4), and as result, the study selected 22 items with five subscales for CSR which were rated high. Factor loadings of the scale items were relatively large, ranging from .916 to .676 . These were significantly more than the minimum acceptable threshold for adequately representing the construct validity of 0.55. Comrey and Lee (1992), suggest that loadings in excess of .55 (30\% overlapping variance) are considered good (71). Also, 18 items were removed from analysis due to the lack of correlation with the theoretical bases of generated factor, and also, for which the factor loading was less than .55. The number of factors generated in this study was determined by combining the following criteria:

(a) Initial recognition of number of factors based on literature review, (b) Scree test of eigenvalues plotted against factors, (c) The Kaiser-Guttman rule (also referred to as "the eigenvalues $>1.0$ rule"), (d) Use the amount of variance extracted, and (e) The ability to understand of the factor extracted.

Results of EFA show the existence of five clean dimensions explaining $50.827 \%$ of the total variance. The first factor had five items and explained the largest variance $(15.436 \%)$ and clearly represented the Economic Responsibility dimension of the CSR. The second factor contained five items, and this explained $10.231 \%$ of the total variance and corresponded with the Philanthropic Responsibility dimension of the construct. The third factor had four items, explaining $9.145 \%$ of the total variance and corresponding to the Ethical Responsibility dimension of the construct. The fourth factor contained four items, and this explained $8.047 \%$ of the total variance and corresponded with the Legal Responsibility dimension of the CSR. Finally, the fifth factor contained four items, and this explained $7.969 \%$ of the total variance and corresponded with the Environmental Responsibility dimension of the construct. Descriptive factor label was applied to naming the factors. The descriptive approach to factor naming involves selecting a label that best reflects the substance of the variables loaded highly and near zero on a factor. Furthermore, the Kaiser-Meyer-Olkin (KMO) measure of sampling adequacy was used to assess the appropriateness of factor analysis. The KMO measure was computed and the results indicate an index of .927, ensuring an excellent sampling adequacy and supporting the factor structures determined. Also, Bartlett's Test of Sphericity indicated that the correlations in a correlation matrix were not zero $\left(\chi^{2}[780]=18436.947\right.$; $\mathrm{p}=.001)$ Reliability of the scale was assessed using Cronbach's alpha. The values of Cronbach's alpha obtained for five factors ranged from 0.848 to 0.967 , indicating very good 
reliability scores and exceeding the $0.70 \quad$ threshold cited in the literature.

Table 4. Results of factor analysis and reliability coefficients

\begin{tabular}{|c|c|c|c|c|c|}
\hline Scale items & $\begin{array}{c}\text { Economic } \\
\text { Responsibility }\end{array}$ & $\begin{array}{l}\text { Philanthropic } \\
\text { Responsibility }\end{array}$ & $\begin{array}{c}\text { Ethical } \\
\text { Responsibility }\end{array}$ & $\begin{array}{c}\text { Legal } \\
\text { Responsibility }\end{array}$ & $\begin{array}{l}\text { Environmental } \\
\text { Responsibility }\end{array}$ \\
\hline $\begin{array}{l}\text { Giving importance to fans' } \\
\text { satisfactions (SR1) }\end{array}$ & .888 & & & & \\
\hline $\begin{array}{l}\text { Trying to achieve long-term } \\
\text { and sustained success (SR6) }\end{array}$ & .884 & & & & \\
\hline $\begin{array}{l}\text { Keep a strict control over } \\
\text { costs (SR11) }\end{array}$ & .876 & & & & \\
\hline $\begin{array}{l}\text { Trying to maximize profits } \\
\text { (SR16) }\end{array}$ & .873 & & & & \\
\hline $\begin{array}{l}\text { Endeavors to increase fans } \\
\text { (SR21) }\end{array}$ & .866 & & & & \\
\hline $\begin{array}{l}\text { Supporting cultural and social } \\
\text { events in the community } \\
\text { (SR2) }\end{array}$ & & .857 & & & \\
\hline $\begin{array}{l}\text { Financial and non-financial } \\
\text { support to NGOs (SR7) } \\
\text { supporting activities related }\end{array}$ & & .849 & & & \\
\hline $\begin{array}{l}\text { to health and wellness in the } \\
\text { community (SR12) }\end{array}$ & & .805 & & & \\
\hline $\begin{array}{l}\text { Helping to solve social and } \\
\text { ethical problems in the } \\
\text { community (SR17) }\end{array}$ & & .796 & & & \\
\hline $\begin{array}{l}\text { Committed to improving the } \\
\text { welfare of the community } \\
\text { (SR22) }\end{array}$ & & .675 & & & \\
\hline $\begin{array}{l}\text { Obeying the principle of fair } \\
\text { play in the competition (SR3) }\end{array}$ & & & .916 & & \\
\hline $\begin{array}{l}\text { Obeying ethical norm which } \\
\text { society requires (SR8) }\end{array}$ & & & .899 & & \\
\hline $\begin{array}{l}\text { Accountability to fans' } \\
\text { criticisms and demands } \\
\text { (SR13) }\end{array}$ & & & .897 & & \\
\hline $\begin{array}{l}\text { Avoiding unethical behavior } \\
\text { (SR18) }\end{array}$ & & & .883 & & \\
\hline $\begin{array}{l}\text { Trying to implementation of } \\
\text { rules and regulations (SR4) }\end{array}$ & & & & .787 & \\
\hline Respecting the rights of fans & & & & & \\
\hline $\begin{array}{l}\text { beyond the legal } \\
\text { requirements (SR9) }\end{array}$ & & & & .779 & \\
\hline $\begin{array}{l}\text { Respecting rules and } \\
\text { regulations defined by law } \\
\text { (SR14) }\end{array}$ & & & & .767 & \\
\hline $\begin{array}{l}\text { Ensure that operation meets } \\
\text { all legal standards (SR19) }\end{array}$ & & & & .756 & \\
\hline $\begin{array}{l}\text { Considering sustainable } \\
\text { development for future } \\
\text { generations (SR5) }\end{array}$ & & & & & .738 \\
\hline $\begin{array}{l}\text { Trying to protective the } \\
\text { environmental (SR10) }\end{array}$ & & & & & .738 \\
\hline $\begin{array}{l}\text { Environmental awareness } \\
\text { training for fans (SR15) }\end{array}$ & & & & & .707 \\
\hline $\begin{array}{l}\text { Trying to use renewable } \\
\text { resources (SR20) }\end{array}$ & & & & & .676 \\
\hline $\begin{array}{l}\text { Percentage of variance } \\
\text { explained }\end{array}$ & 15.436 & 10.231 & 9.145 & 8.047 & 7.969 \\
\hline $\begin{array}{l}\text { Cumulative } \% \text { of variance } \\
\text { explained }\end{array}$ & 15.436 & 25.667 & 34.812 & 42.859 & 50.827 \\
\hline Cronbach's alpha & .967 & .903 & .943 & .898 & .848 \\
\hline
\end{tabular}


Validation of the Measurement Scale. To test the adequacy of the new CSR measurement scale, a quantitative study based on personal surveys of fans were designed. As Churchill (1979), propose, the first step in the validation of a measurement scale is the development of a Confirmatory Factor Analysis (CFA) (59). To evaluate the psychometric properties of reliability and validity for the proposed measurement scale, first- and second-order CFA were performed. The reliability of the measurement scale was evaluated by composite reliability (CR) an average variance extracted (AVE). The value greater than .50 of the AVE score was judged as a reliable value, also, the value exceeding .70 of the CR was regarded as a reliable value respectively (72). In addition, all items are significant at a confidence level of
$95 \%$, and standardized lambda coefficients are above .5 , confirming the convergent validity of the model. Discriminate validity among measured constructs was assessed with the correlations between these constructs from CFA. When the confidence interval of the estimated correlation between two constructs does not include 1, a researcher can use this as a supporting evidence for discriminate validity of these two constructs. Another evidence for discriminate validity was that estimated correlations among constructs are less than .85 suggested by Kline (2011). The positive correlation coefficients indicate positive relationships between the CSR dimensions. Thus, the criterion validity of the scale was acceptable (Table 5). Therefore, the proposed measurement model is acceptable (Table 6).

Table 5. Discriminate Validity

\begin{tabular}{|c|c|c|c|c|c|}
\hline & Economic & Philanthropic & Ethical & Legal & Environmental \\
\hline Economic & 1 & & & & \\
\hline Philanthropic & $\begin{array}{l}r=.79 \\
p=.02\end{array}$ & 1 & & & \\
\hline Ethical & $\begin{array}{l}r=.73 \\
p=.02\end{array}$ & $\begin{array}{l}r=.65 \\
p=.03\end{array}$ & 1 & & \\
\hline Legal & $\begin{array}{l}r=.73 \\
p=.02\end{array}$ & $\begin{array}{l}r=.65 \\
p=.03\end{array}$ & $\begin{array}{l}r=.64 \\
p=.03\end{array}$ & 1 & \\
\hline Environmental & $\begin{array}{l}r=.57 \\
p=.03\end{array}$ & $\begin{array}{l}r=.49 \\
p=.04\end{array}$ & $\begin{array}{l}r=.52 \\
p=.03\end{array}$ & $\begin{array}{l}r=.56 \\
p=.03\end{array}$ & 1 \\
\hline
\end{tabular}

Finally, the goodness of fit of the analysis was verified with the Steiger-Lind root mean square error of approximation (RMSEA), a parsimony-corrected index, with its 90\% confidence interval, the Jöreskog-Sörbom Goodness of Fit Index (GFI), an absolute fit index, the Bentler Comparative Fit Index (CFI), an incremental fit index, and Standardized Root Mean Square Residual (SRMR), a statistic related to the correlation residuals, Which are the most common measures for confirmatory tests (63). Additionally, the normed chi-square $\left(\chi^{2} / \mathrm{df}\right)$ was also recommended to measure overall model fit, because of $\chi^{2}$ is sensitivity in samples exceeding 200 units (73). The measurement model was a reasonably good fit to the data $(\chi 2$ $[199]=380.62, \mathrm{p}=.001 ; \mathrm{GFI}=.95 ; \mathrm{CFI}=1$; RMSEA $=.039$ (.032; .044); SRMR = .025). The value of Chi-square/df ratio was 1.912 . This was lower than the standard value (3.0) suggested by Kline (2011). The CFI was good and higher than the cutoff point for a good fit (.90 or larger) recommended by $\mathrm{Hu}$ and Bentler (1999). The GFI (.95) was also met the criteria (0.95) for acceptable model fit (74). The RMSEA was lower (.039) than the recommended value of .08 (75). The SRMR was lower (.025) than the recommend cut-off value of .08 (75).

\section{RESULTS}

Eventually, with the two first-order factor analyses carried out, exploratory and confirmatory must be completed through the development of a second-order CFA to gain a better understanding of the concept under study. CSR is seen as a second-order factor generated from the relationship between the 
lower order factors of economy, philanthropy, ethic, legal, and environment. Figure 1 shows the final estimates of the second-order model. The goodness-of-fit indices (CFI $=1$, and GFI $=.95)$ exceed the recommended value of .90 , and the RMSEA and SRMR (.027) were lower than the recommend cut-off value of .08 . Therefore, it can be argued that the adjustment of the second-order model is acceptable. The estimated coefficients for the five CSR factors are all positive and significant for a confidence level of $95 \%$. Consequently, these factors accurately represent the underlying concept. The first important result is that sport customers (fans) perceive CSR as a combination of team actions in the economic, philanthropic, ethical, legal and environmental spheres. However, the environmental dimension appears to have less weight within the construct of CSR based on its loading factor. The final CSR measurement scale with all the items is included in appendix.

\begin{tabular}{|c|c|c|c|c|c|}
\hline Latent variable & Measured variable & Standardized lambda & $\mathrm{R}^{2}$ & $\mathrm{CR}$ & AVE \\
\hline \multirow{5}{*}{ Economic } & SR1 & .88 & .77 & .913 & .757 \\
\hline & SR6 & .86 & .73 & & \\
\hline & SR11 & .86 & .74 & & \\
\hline & SR16 & .86 & .75 & & \\
\hline & SR21 & .89 & .79 & & \\
\hline \multirow{5}{*}{ Philanthropic } & SR2 & .85 & .72 & .849 & .628 \\
\hline & SR7 & .82 & .68 & & \\
\hline & SR12 & .79 & .62 & & \\
\hline & SR17 & .77 & .59 & & \\
\hline & SR22 & .73 & .53 & & \\
\hline \multirow{4}{*}{ Ethical } & SR3 & .89 & .79 & .908 & .783 \\
\hline & SR8 & .89 & .79 & & \\
\hline & SR13 & .90 & .81 & & \\
\hline & SR18 & .86 & .73 & & \\
\hline \multirow{4}{*}{ Legal } & SR4 & .77 & .59 & .809 & .644 \\
\hline & SR9 & .84 & .70 & & \\
\hline & SR14 & .81 & .66 & & \\
\hline & SR19 & .79 & .63 & & \\
\hline \multirow{4}{*}{ Environmental } & SR5 & .79 & .62 & .750 & .570 \\
\hline & SR10 & .77 & .59 & & \\
\hline & SR15 & .72 & .51 & & \\
\hline & SR20 & .74 & .54 & & \\
\hline
\end{tabular}

\section{DISCUSSION AND CONCLUSIONS}

According to Carroll (2000), since it is difficult to gather actual measures, there is a tendency to rely on stakeholders' opinions or assessments of performance in the literature (76). Nevertheless, developing comprehensive measures of corporate social activities that really address social performance is a challenge. Because, "if we do less than this, we should not call it social performance" (76). In spite of this apparent risk, relying on stakeholders' views and sustainable development can be a more reliable method of measuring corporate social activities when compared to alternative methods. This line of research is relatively recent, and few studies have tried to provide solid and reliable scales for measuring this concept in the method proposed by this research. Moreover, as argued in the literature, employing the principles of CSR highly depends on the contextual attributes of the sectors to which it is applied (17-19,21). Therefore, the design of measurement scales adjusted to different settings is required for the appropriate understanding of the situation of CSR today. Given the perceived limitations of previous measurement scales, the aim of this 
study was to develop a new tool for measuring CSR in the sport sector according to the perceptions of sport fans. Following Churchill's (1979) methodological proposal, this study incorporated both qualitative and quantitative methods to develop a measurement scale. A panel of experts was set up first to generate a sample of items for further development of a measurement scale. In order to test the adequacy of this new CSR measurement scale, a quantitative study based on personal surveys of fans of football teams in Iran's Premier League was designed. A total of 640 questionnaires were collected. After an elaborate scale development process, the current structure of the scale provides some important implications.

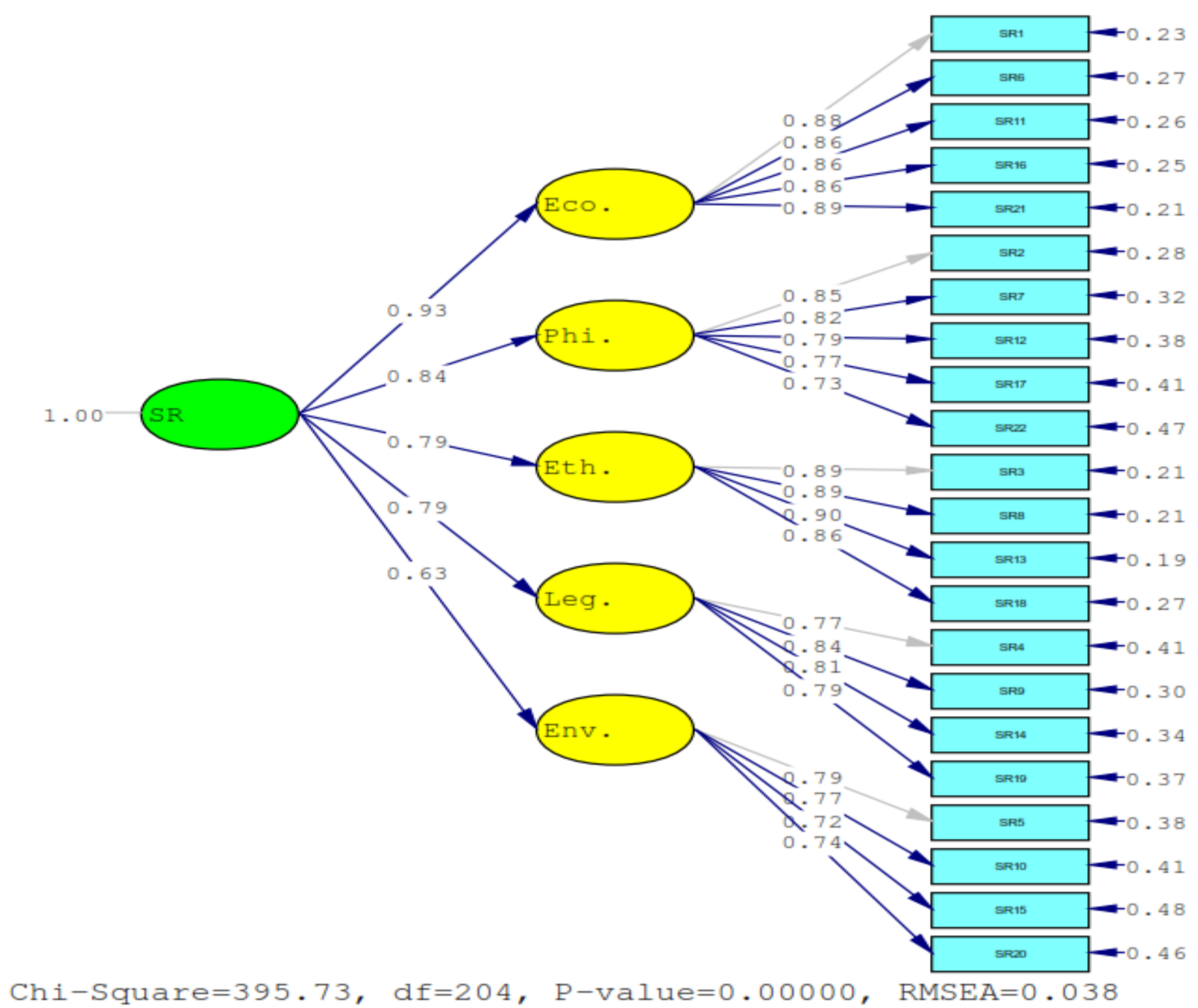

Figure 1. Second-Order CFA of the Dimensions of Corporate Social Responsibility

The interesting result of this study is the confirmation of the multidimensional nature of CSR, which is in line with the findings of previous research $(43,48,60,61,64,68,69,77,78)$, undermining the fact that the theoretical frameworks employed in some of these studies are different from those employed in the present research. We demonstrate that, from a consumer's perspective, CSR is perceived as a set of economic, philanthropic, ethical, legal, and environmental attributes. In this sense, the acceptance of economic, philanthropic, ethical, and legal dimensions of CSR by sport consumers supports previous findings $(11,21,78-80)$. Moreover, the acceptance of an environmental dimension of CSR by sport fans is in line with 
the findings of previous research (29,39-41). This new CSR environmental focus in sport is driven by changing societal values and increased engagement with and expectations by a variety of stakeholders. Moreover, these types of CSR practices could have economic and legitimacy benefits for a sport organization (39). Thus, in this study, combining sustainable development and Carroll's (1979) model from the perspective of sport consumers (as stakeholder) for a multidimensional scale for the measurement of social responsibility in sport industry was confirmed. The results showed that giving importance to fans' satisfactions, trying to achieve long-term and sustained success, endeavors to increase fans, keeping a strict control over costs, and trying to maximize profits appears to be important factors in sport teams' economic responsibility. The ultimate goal of improving performance of professional sport team was to increase their profitability and stabilize operation, and then make contributions to the society (78). These findings are in line with the work of Carroll and Shabana (2010) that enterprises need to have profitability then fulfill their corporate social responsibility (81), and Huang et al (2015) that professional sport teams have to value players' rights (54). The results showed that supporting cultural and social events in the community, financial and non-financial support to NGOs, supporting activities related to health and wellness in the community, helping to solve social and ethical problems in the community, and commitment to enhancing the welfare of the community seems to be important factors in sport teams' philanthropic responsibility. Philanthropic events are most popular CSR practice in professional sport organisations (79). These findings are in accordance with the research by Godfrey (2009) that sport organizations are already devoted to the promotion of community activities (e.g. stayin-school initiatives) which have positive impacts on the society (20). Enhancing the relationship between sport organizations and local community may attract local fans' support, and willingness to buy tickets and merchandise (79). The results indicated that obeying the principle of fair play in the competition, obeying ethical norm required by the society, accountability to fans' criticisms and demands, and avoiding unethical behavior seem to be important factors in sport organizations' ethical responsibility. From the sport organization managements' point of view, doping and sportsmanship issues are overlapped with hypocrisy, once players' unethical behavior was exposed, many team managers would use CSR (doing good things) to strategically avoid criticism (79). CSR is an important strategy employed by organizations to manage their reputation. The results demonstrate that trying to implement rules and regulations, respecting the rights of fans beyond the legal requirements, respecting rules and regulations defined by law and ensuring that operation meets all legal standards appear to be important factors in sport teams' legal responsibility. The rules and regulations were created for the interests of the majority, thus all people, organizations, and enterprises are required to comply with them $(21,82)$. The results show that considering sustainable development for future generations, trying to protect the environment, environmental awareness training for fans, and trying to use renewable resources appear to be important factors in sport teams' environmental responsibility. These findings are in line with research by Trendafilova et al. (2013) and Trendafilova and Nguyen (2015), in which the relationship between sport and environment are inseparable, it is the duty and responsibility of every sportsman to protect the environment. Furthermore, the specific perceptions of different stakeholders of the responsibilities that must be assumed by a sport team have rarely been discussed in academic research. The consumer evaluations of sport industry with respect to each of the dimensions of CSR in which sport related businesses are involved represent an important finding. Moreover, in view of the assessment of the philanthropic and environmental dimensions, our findings highlight several areas of opportunity for improvement with important implications for managers of sport teams. First, issues related to team actions that directly benefit society-such as helping to solve social and ethical problems, supporting activities related to health and wellness, commitment to improve the welfare of the communities in which they operate, supporting cultural and social events, environmental awareness training 
for fans, trying to use renewable resources, indicate that sport clubs should devote resources and effort to strengthening actions in this area.

\section{LIMITATIONS AND FUTURE RESEARCH}

Finally, to refine the findings of this study, some limitations of this work are outlined below, nevertheless, we argue that these should be seen as opportunities to design and develop robust future studies. First, although the proposed measurement scale employs a balanced combination of factors in each of the dimensions and provides a useful tool for measuring CSR in sport industry, not all items described in the literature are used in the model presented here. As earlier mentioned, for the initial development of the measurement scale, 40 items of interest were selected from the marketing and sport literature on CSR. Nevertheless, there may be other items that more fully encompass the concept of CSR and its contextual characteristics.

Second, the fact of obtaining our data in the football sector does not imply that the results of this research can be extrapolated to other sectors and fields in the sport industry. So, it would be important to replicate this research in other sectors of the sport industry, such as sport federations, to generalize the results obtained.

Third, as suggested by Churchill (1979), researchers can employ the procedures described in his study with certain flexibilities and the recommended techniques can be substituted with other alternatives. The alternatives employed in the current study included incorporating a panel of experts and the assessment of criterion validity with convergent validity and discriminate validity. We consider that future studies may follow the procedure suggested by this author including all the steps in order to guarantee better measures of CSR measurement scales.

Fourth, the crosscutting nature of this study prevents an understanding of the differences in the perceptions of the fans surveyed over time, suggesting that this study could be extended by a longitudinal study. It would, therefore, be interesting to repeat the study once the sport industry has recovered. Similarly, it would be interesting to examine the moderating role of certain demographic characteristics-like education, age, or occupation-since the existence of differences in the perceptions of sport consumers in their assessment regarding CSR dimensions could be analyzed. In conclusion, although the results of this study demonstrate an admissible structure for the measurement of CSR, there is an obvious need for further investigation to confirm the results. In particular, studies in different countries with other sociocultural, political, or economic contexts would greatly benefit this field of research and stimulate further discussion and analysis of perceptions of CSR.

\section{APPLICABLE REMARKS}

- This finding should encourage sport teams to strengthen ties with their fans to ensure that they are less vulnerable to changes in their local communities and to actions by competitors.

- It is important for a professional sports team's management to understand fans' interest in social issues and fans' responses to various CSR programs.

- Regarding the valid and reliable instrument for measuring social responsibility in sport industry, it is suggested for sport managers and marketers to employ this tool to assess and audit social responsibility performance of sport teams and clubs for improve performance and development of strategies.

\section{REFERENCES}

1. Vaaland TI, Heide M, Grønhaug K. Corporate social responsibility: investigating theory and research in the marketing context. Eur J Mark [Internet]. 2008;42(9/10):927-53. Available from: http://www.emeraldinsight.com/doi/abs/10.1108/03090560810891082 
2. Tacon R, Walters G. Corporate Social Responsibility in Sport: Stakeholder Management in the UK Football Industry. J Manag Organ. 2010;16(4):566-86.

3. Anderson JW. Corporate Social Responsibility. Connecticut, USA: Greenwood Press; 1989.

4. Giroux M, Pons F, Mourali M. Is CSR Important for All Types of Fans?: The Value of Corporate Social Responsibility in Sport. In: Robinson JL, editor. Marketing Dynamism \& Sustainability: Things Change, Things Stay the Same...: Proceedings of the 2012 Academy of Marketing Science (AMS) Annual Conference [Internet]. Cham: Springer International Publishing; 2015. p. 497-500. Available from: http://dx.doi.org/10.1007/978-3319-10912-1_164

5. Cappato A, Pennazio V. Corporate Social Responsibility in Sport Torino 2006 Olympic Winter Games. Turin, Italy: University of Turin; 2006.

6. Filizöz B, Fişne M. Corporate Social Responsibility: A Study of Striking Corporate Social Responsibility Practices in Sport Management. Procedia Soc Behav Sci. 2011;24:1405-17.

7. Chang MJ, Ko YJ, Connaughton DP, Kang J-H. The effects of perceived CSR, pride, team identification, and regional attachment: the moderating effect of gender. J Sport Tour [Internet]. Routledge; 2016;1-15. Available from: http://dx.doi.org/10.1080/14775085.2016.1193822

8. Kulczycki W, Koenigstorfer J. Doing good in the right place: city residents' evaluations of professional football teams' local (vs. distant) corporate social responsibility activities. Eur Sport Manag Q [Internet]. Routledge; 2016;1-23. Available from: http://dx.doi.org/10.1080/16184742.2016.1164736

9. Hess DW. The Framework for CSR Assessment, Measurement, and Reporting. In: Okonkwo B, editor. Christian Ethics and Corporate Culture: A Critical View on Corporate Responsibilities [Internet]. Cham: Springer International Publishing; 2014. p. 177-92. Available from: http://dx.doi.org/10.1007/978-3-319-00939-1_13

10. Scheinbaum AC, Lacey R. Event social responsibility: A note to improve outcomes for sponsors and events. J Bus Res. 2015;68(9):1982-6.

11. Walker M, Kent A. Do Fans Care? Assessing the Influence of Corporate Social Responsibility on Consumer Attitudes in the Sport Industry. J Sport Manag. 2009;23:743-69.

12. Jones TM. Corporate Social Responsibility Revisited, Redefined. Calif Manage Rev [Internet]. 1980;22(3):59-67. Available from: http://cmr.ucpress.edu/content/ucpcmr/22/3/59.full.pdf

13. Mohr LA, Webb DJ, Harris KE. Do Consumers Expect Companies to be Socially Responsible? The Impact of Corporate Social Responsibility on Buying Behavior. J Consum Aff [Internet]. Blackwell Publishing Ltd; 2001;35(1):45-72. Available from: http://dx.doi.org/10.1111/j.1745-6606.2001.tb00102.x

14. Kotler P, Armstrong G. Principles of Marketing [Internet]. 16th ed. Pearson Education, Limited; 2015. Available from: https://books.google.com/books?id=xgv9rQEACAAJ

15. Wood DJ. Measuring Corporate Social Performance: A Review. Int J Manag Rev [Internet]. Blackwell Publishing Ltd; 2010;12(1):50-84. Available from: http://dx.doi.org/10.1111/j.1468-2370.2009.00274.x

16. Walker M, Heere B, Parent MM, Drane D. Social Responsibility and the Olympic Games: The Mediating Role of Consumer Attributions. J Bus Ethics. 2010;95:659-80.

17. Campbell JL. Why would corporations behave in socially responsible ways? an institutional theory of corporate social responsibility. Acad Manag Rev [Internet]. 2007;32(3):946-67. Available from: http://amr.aom.org/content/32/3/946.abstract

18. Decker OS. Corporate social responsibility and structural change in financial services. Manag Audit $\mathbf{J}$ [Internet]. 2004;19(6):712-28.

http://www.emeraldinsight.com/doi/abs/10.1108/02686900410543840

19. Whitehouse L. Corporate Social Responsibility: Views from the Frontline. J Bus Ethics [Internet]. 2006;63(3):279-96. Available from: http://dx.doi.org/10.1007/s10551-005-3243-0

20. Godfrey P. Corporate social responsibility in sport: An overview and key issues. J Sport Manag. 2009;23(6):698-716.

21. Carroll AB. A three-dimensional conceptual model of corporate performance. Acad Manag Rev. 1979;4(4):497-505.

22. Salmones M del MG de los, Crespo AH, Bosque IR del. Influence of Corporate Social Responsibility on Loyalty and Valuation of Services. J Bus Ethics [Internet]. Kluwer Academic Publishers; 2005 Nov [cited 2016 Aug 5];61(4):369-85. Available from: http://link.springer.com/10.1007/s10551-005-5841-2

23. Freeman RE. Business Ethics at the Millennium. Bus Ethics Q [Internet]. 2000;10(1):169-80. Available from: http://dx.doi.org/10.2307/3857703

24. Swaen V, Chumpitaz RC. Impact of Corporate Social Responsibility on Consumer Trust. Rech Appl en Mark (English Ed [Internet]. 2008;23(4):7-34. Available from: http://rme.sagepub.com/content/23/4/7.abstract

25. European Commission. Corporate Social Responsibility: A business contribution to sustainable 
development. Office for Official Publications of the European Communities; 2002.

26. Martínez P, del Bosque IR. CSR and customer loyalty: The roles of trust, customer identification with the company and satisfaction. Int J Hosp Manag. 2013;35:89-99.

27. Pérez A, Rodríguez del Bosque I. An Integrative Framework to Understand How CSR Affects Customer Loyalty through Identification, Emotions and Satisfaction. J Bus Ethics [Internet]. 2015;129(3):571-84. Available from: http://dx.doi.org/10.1007/s10551-014-2177-9

28. Pérez A, del Bosque IR. Corporate social responsibility and customer loyalty: exploring the role of identification, satisfaction and type of company. J Serv Mark. 2015;29(1):15-25.

29. Babiak K, Wolfe R. Determinants of corporate social responsibility in professional sport: Internal and external factors. J Sport Manag. 2009;23:717-42.

30. Carroll AB. The Four Faces of Corporate Citizenship. Bus Soc Rev [Internet]. Blackwell Publishers Ltd.; 1998;100-101(1):1-7. Available from: http://dx.doi.org/10.1111/0045-3609.00008

31. Sethi SP. Dimensions of Corporate Social Performance: An Analytical Framework. Calif Manage Rev [Internet]. 1975;17(3):58-64. Available from: http://cmr.ucpress.edu/content/ucpcmr/17/3/58.full.pdf

32. Ward H, Borregaard N, Kapelus P. Corporate citizenship: Revisiting the relationship between business, good governance and sustainable development. Johannesbg Int Inst Environ Dev. 2002;1-6.

33. Vidal NG, Kozak RA. Corporate Responsibility Practices in the Forestry Sector: Definitions and the Role of Context. J Corp Citizsh [Internet]. 2008;2008(31):58-75. Available from: http://www.ingentaconnect.com/content/glbj/jcc/2008/00002008/00000031/art00009

34. Stewart B, Smith A. The Special Features of Sport. Ann Leis Res [Internet]. Routledge; 1999;2(1):87-99. Available from: http://dx.doi.org/10.1080/11745398.1999.10600874

35. Breitbarth T, Harris P. The Role of Corporate Social Responsibility in the Football Business: Towards the Development of a Conceptual Model. Eur Sport Manag Q. 2008;8(2):179-206.

36. Gladwin TN, Kennelly JJ, Krause T-S. Shifting Paradigms for Sustainable Development: Implications for Management Theory and Research. Acad Manag Rev [Internet]. 1995;20(4):874-907. Available from: http://amr.aom.org/content/20/4/874.abstract

37. Kakabadse NK, Rozuel C, Lee-Davies L. Corporate social responsibility and stakeholder approach: a conceptual review. Int J Bus Gov Ethics [Internet]. 2005;1(4):277-302. Available from: http://www.inderscienceonline.com/doi/abs/10.1504/IJBGE.2005.006733

38. Levermore R. CSR for Development Through Sport: examining its potential and limitations. Third World Q [Internet]. Routledge; 2010;31(2):223-41. Available from: http://dx.doi.org/10.1080/01436591003711967

39. Babiak K, Trendafilova S. CSR and environmental responsibility: motives and pressures to adopt green management practices. Corp Soc Responsib Environ Manag [Internet]. John Wiley \& Sons, Ltd.; 2011;18(1):1124. Available from: http://dx.doi.org/10.1002/csr.229

40. Trendafilova S, Nguyen S. Corporate Social Responsibility and the environment in the sport industry. In: Casper JM, Pfahl ME, editors. Sport Management and the Natural Environment: Theory and Practice. First Edit. Routledge; 2015. p. 76-87.

41. Trendafilova S, Babiak K, Heinze K. Corporate social responsibility and environmental sustainability: Why professional sport is greening the playing field. Sport Manag Rev. 2013;16:298-313.

42. D'Aprile G, Talò C. Measuring Corporate Social Responsibility as a Psychosocial Construct: A New Multidimensional Scale. Empl Responsib Rights J [Internet]. 2013;26(3):153-75. Available from: http://dx.doi.org/10.1007/s10672-013-9228-8

43. Turker D. Measuring Corporate Social Responsibility: A Scale Development Study. J Bus Ethics [Internet]. 2009;85(4):411-27. Available from: http://dx.doi.org/10.1007/s10551-008-9780-6

44. van Oosterhout J, Heugens PPMAR. Much Ado About Nothing: A Conceptual Critique of CSR [Internet]. 2006 [cited 2016 Aug 5]. Available from: http://ssrn.com/abstract=924505

45. Bragdon Jr JH, Marlin JA. Is Pollution Profitable? Risk Manag. 1972;19:9-18.

46. Griffin JJ, Mahon JF. The Corporate Social Performance and Corporate Financial Performance Debate: Twenty-Five Years of Incomparable Research. Bus Soc [Internet]. 1997;36(1):5-31. Available from: http://bas.sagepub.com/content/36/1/5.abstract

47. Stanwick PA, Stanwick SD. The Relationship Between Corporate Social Performance, and Organisational Size, Financial Performance, and Environmental Performance: An Empirical Examination. In: Michalos CA, Poff $\mathrm{CD}$, editors. Citation Classics from the Journal of Business Ethics: Celebrating the First Thirty Years of Publication [Internet]. Dordrecht: Springer Netherlands; 2013. p. 513-24. Available from: http://dx.doi.org/10.1007/978-94-007-4126-3_26

48. Maignan I, Ferrell OC, Ferrell L. A stakeholder model for implementing social responsibility in marketing. 
Eur J Mark [Internet]. 2005;39(9/10):956-77. Available from: http://www.emeraldinsight.com/doi/abs/10.1108/03090560510610662

49. McGuire JB, Sundgren A, Schneeweis T. Corporate Social Responsibility and Firm Financial Performance. Acad Manag J [Internet]. 1988;31(4):854-72. Available from: http://amj.aom.org/content/31/4/854.abstract

50. Maignan I, Ferrell OC. Corporate citizenship as a marketing instrument - Concepts, evidence and research directions. Eur J Mark [Internet]. 2001;35(3/4):457-84. Available from: http://www.emeraldinsight.com/doi/abs/10.1108/03090560110382110

51. Lantos GP. The boundaries of strategic corporate social responsibility. J Consum Mark [Internet]. 2001;18(7):595-632. Available from: http://www.emeraldinsight.com/doi/abs/10.1108/07363760110410281

52. Freeman RE. Strategic management: A stakeholder approach. Boston, MA: Pitnam; 1984.

53. Coady L, Snider S, Duffy A, Legg R. Corporate social responsibility for the Vancouver 2010 olympic and paralympic winter games: Adopting and adapting best practices. Corp Soc Responsib Rev Autumn. 2007;11-5.

54. Huang F-H, Ye Y-J, Kao C-H. Developing a novel Intuitionistic Fuzzy Importance-performance Analysis for evaluating corporate social responsibility in sport tourism event. Expert Syst Appl [Internet]. 2015;42(19):6530-8. Available from: http://www.sciencedirect.com/science/article/pii/S0957417415002389

55. Turker D. An Analysis of Corporate Social Responsibility in the Turkish Business Context. In: Idowu OS, Schmidpeter R, Fifka SM, editors. Corporate Social Responsibility in Europe: United in Sustainable Diversity [Internet]. Cham: Springer International Publishing; 2015. p. 483-99. Available from: http://dx.doi.org/10.1007/978-3-319-13566-3_26

56. Furrer P. Sustainable Olympic Games: A dream or a reality? Boll della Soc Geogr Ital. 2002;7(4):1-31.

57. International Olympic Committee. What is the Olympic Games global impact study? Focus Olympic Review. 2006. p. 1-2.

58. VanWynsberghe R, Derom I, Maurer E. Social leveraging of the 2010 Olympic Games: "sustainability" in a City of Vancouver initiative. J Policy Res Tour Leis Events [Internet]. Routledge; 2012;4(2):185-205. Available from: http://dx.doi.org/10.1080/19407963.2012.662618

59. Churchill GA. A Paradigm for Developing Better Measures of Marketing Constructs. J Mark Res [Internet]. American Marketing Association; 1979;16(1):64-73. Available from: http://www.jstor.org/stable/3150876

60. Martínez P, Pérez A, Rodríguez del Bosque I. Measuring Corporate Social Responsibility in tourism: Development and validation of an efficient measurement scale in the hospitality industry. J Travel Tour Mark [Internet]. Routledge; 2013;30(4):365-85. Available from: http://dx.doi.org/10.1080/10548408.2013.784154

61. Pérez A, Martínez P, Rodríguez del Bosque I. The development of a stakeholder-based scale for measuring corporate social responsibility in the banking industry. Serv Bus [Internet]. 2013;7(3):459-81. Available from: http://dx.doi.org/10.1007/s11628-012-0171-9

62. Anderson JC, Gerbing DW. Structural equation modeling in practice: A review and recommended two-step approach. Psychol Bull. 1988;103(3):411-23.

63. Kline RB. Principles and Practice of Structural Equation Modeling. New York: Guilford Press; 2011.

64. Agudo Valiente JM, Garcés Ayerbe C, Salvador Figueras M. Social responsibility practices and evaluation of corporate social performance. J Clean Prod [Internet]. 2012;35:25-38. Available from: http://www.sciencedirect.com/science/article/pii/S0959652612002259

65. Galbreath J. How does corporate social responsibility benefit firms? Evidence from Australia. Eur Bus Rev [Internet]. 2010;22(4):411-31. Available from: http://www.emeraldinsight.com/doi/abs/10.1108/09555341011056186

66. Lichtenstein DR, Drumwright ME, Braig BM. The effect of corporate social responsibility on customer donations to corporate-supported nonprofits. J Mark. 2004;68(4):16-32.

67. Ramasamy B, Yeung M. Chinese Consumers' Perception of Corporate Social Responsibility (CSR). J Bus Ethics [Internet]. 2009;88(1):119-32. Available from: http://dx.doi.org/10.1007/s10551-008-9825-x

68. Walters G, Tacon R. Corporate social responsibility in European football [Internet]. Birkbeck College, University of London; 2011. Available from: http://eprints.bbk.ac.uk/7618/

69. Turker D. Islamic Roots of Corporate Social Responsibility. In Springer International Publishing; 2016 [cited 2016 Sep 19]. p. 133-44. Available from: http://link.springer.com/10.1007/978-3-319-28287-9_10

70. Brown TA. Confirmatory Factor Analysis for Applied Research. New York: The Guilford Press; 2006.

71. Comrey AL, Lee HB. A first course in factor analysis. 2nd ed. New York: Psychology Press, Taylor \& Francis Group; 1992.

72. Hair JF, Black WC, Babin BJ, Anderson RE. Multivariate data analysis. 7th ed. London: Pearson; 2009. 816 p.

73. Bollen KA. A New Incremental Fit Index for General Structural Equation Models. Sociol Methods Res 
[Internet]. 1989;17(3):303-16. Available from: http://smr.sagepub.com/content/17/3/303.abstract

74. Hooper D, Coughlan J, Mullen M. Structural equation modelling: Guidelines for determining model fit. Electron J Bus Res Methods. 2008;6(1):53-60.

75. $\mathrm{Hu} \mathrm{L}$, Bentler PM. Cutoff criteria for fit indexes in covariance structure analysis: Conventional criteria versus new alternatives. Struct Equ Model A Multidiscip J [Internet]. Routledge; 1999;6(1):1-55. Available from: http://dx.doi.org/10.1080/10705519909540118

76. Carroll AB. A Commentary and an Overview of Key Questions on Corporate Social Performance Measurement. Bus Soc [Internet]. 2000;39(4):466-78. Available from: http://bas.sagepub.com/content/39/4/466.abstract

77. Breitbarth T, Hovemann G, Walzel S. Scoring strategy goals: Measuring corporate social responsibility in professional European football. Thunderbird Int Bus Rev [Internet]. Wiley Subscription Services, Inc., A Wiley Company; 2011;53(6):721-37. Available from: http://dx.doi.org/10.1002/tie.20448

78. Chen BH, Chen M-H, Tai P-N, Hsiung W-C. Constructing the Corporate Social Responsibility Indicators of Professional Sport Organisation. Int J Bus Adm. 2015;6(5):75-81.

79. Sheth H, Babiak K. Beyond the game: Perceptions and practices of corporate social responsibility in the professional sport industry. J Bus Ethics. 2010;91(3):433-50.

80. Chelladurai P. Corporate Social Responsibility and Discretionary Social Initiatives in Sport: A Position Paper. J Glob Sport Manag [Internet]. Routledge; 2016 Apr 2;1(1-2):4-18. Available from: http://www.tandfonline.com/doi/abs/10.1080/24704067.2016.1177355

81. Carroll AB, Shabana KM. The Business Case for Corporate Social Responsibility: A Review of Concepts, Research and Practice. Int J Manag Rev [Internet]. 2010 Mar [cited 2016 Aug 4];12(1):85-105. Available from: http://doi.wiley.com/10.1111/j.1468-2370.2009.00275.x

82. Carroll AB. Corporate Social Responsibility: Evolution of a Definitional Construct . Bus Soc [Internet]. 1999 Sep 1;38(3):268-95. Available from: http://bas.sagepub.com/content/38/3/268.abstract 


\section{Appendix}

See Table 7

Table 7. Measurement scale for CSR in sport industry

\begin{tabular}{|c|c|}
\hline Ident. & Item \\
\hline \multicolumn{2}{|c|}{ I believe that this team $(X)$. } \\
\hline SR1. & Gives importance to fans' satisfactions. \\
\hline SR2. & Supports cultural and social events in the community \\
\hline SR3. & Obeys the principle of fair play in the all competition \\
\hline SR4. & Tries to implementation of rules and regulations \\
\hline SR5. & Considers sustainable development for future generations \\
\hline SR6. & Tries to achieve long-term and sustained success \\
\hline SR7. & Has Financial and non-financial supports to NGOs \\
\hline SR8. & Obeys ethical norm which society requires \\
\hline SR9. & Respects the rights of fans beyond the legal requirements \\
\hline SR10. & Tries to protective the environmental \\
\hline SR11. & Keeps a strict control over their costs \\
\hline SR12. & supports activities related to health and wellness in the community \\
\hline SR13. & Is accountable to fans' criticisms and demands \\
\hline SR14. & Respects rules and regulations defined by law \\
\hline SR15. & Provides environmental awareness training to fans \\
\hline SR16. & Tries to maximize their profits \\
\hline SR17. & Helps to solve social and ethical problems in the community \\
\hline SR18. & Avoids unethical behaviors \\
\hline SR19. & Ensures that their operations meets all legal standards \\
\hline SR20. & Tries to use renewable resources. \\
\hline SR21. & Endeavors to increase their fans \\
\hline SR22. & Is committed to improving the welfare of the community \\
\hline \multicolumn{2}{|c|}{ 7-Point Likert scale ( $1=$ strongly disagree with the sentence; $7=$ strongly agree) } \\
\hline \multirow{2}{*}{\multicolumn{2}{|c|}{$\begin{array}{l}\text { Economic Responsibility: SR1, SR6, SR11, SR16, SR21 } \\
\text { Philanthronic Resnonsibility SR2 SR7 SR12 SR17 SR22 }\end{array}$}} \\
\hline \multirow{2}{*}{\multicolumn{2}{|c|}{ Philanthropic Responsibility: SR2, SR7, SR12, SR17, SR22 }} \\
\hline & \\
\hline \multicolumn{2}{|c|}{ Legal Responsibility: SR4, SR9, SR14, SR19 } \\
\hline \multicolumn{2}{|c|}{ Environmental Responsibility: SR5, SR10, SR15, SR20 } \\
\hline
\end{tabular}

